\title{
Antinociceptive, cytotoxic and antibacterial activities of Cleome viscosa leaves
}

\section{Utpal Bose, ${ }^{*}, 1$ Vaskor Bala, ${ }^{1}$ Tarak Nath Ghosh, ${ }^{1}$ Karthikeyan Gunasekaran, ${ }^{2}$ Ahmed Ayedur Rahman ${ }^{1}$}

${ }^{1}$ Pharmacy Discipline, Khulna University, Bangladesh,

${ }^{2}$ Karthikeyan Gunasekaran, School of Biotechnology and Biomolecular Sciences, University of New South Wales, Australia.
Revista Brasileira de Farmacognosia Brazilian Journal of Pharmacognosy 21(1): 165-169, Jan./Feb. 2011

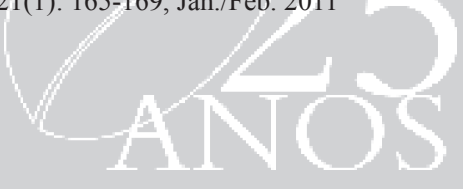

Article

Received 7 Jul 2010

Accepted 26 Aug 2010

Available online $25 \mathrm{Feb} 2011$

Keywords: antinociceptive cytotoxic antibacterial Cleome viscosa Capparidaceae

ISSN 0102-695X doi: $10.1590 / \mathrm{S} 0102-695 \mathrm{X} 2011005000023$

\section{Introduction}

Cleome viscosa L., Cleomaceae, is a widely distributed sticky herb with yellow flowers and long slender pods containing seeds, which similar those of mustard (Hindi), Hurhuria (Bengali), Nayikkadugu (Tamil) in South Asian folk medicine, found throughout the larger part of Indian Subcontinent, often in waste places (Tandon et al., 2010). The plant finds its use in the traditional system of local medicine as a laxative and diuretic (Mali, 2010). It is reported to be useful in the treatment of malarial fevers, fever due to indigestion, skin diseases, leprosy, blood diseases, and uterine complaints (Kirtikar \& Basu, 1984). In the Unani system of medicine, the seeds of the plant are documented as anthelmintic and detergent, and are given to treat fever and diarrhoea (Chopra et al., 1956). The seeds are used for anthelmintic while the leaves are useful for healing wounds (Parimaladevi et al., 2003). A poultice made from the plant is efficacious as a counterirritant in chronic painful joints. Juice is used to remove pus from ear (Nadkararni, 1976). Fatty constituents of the seed oil of C. viscosa have been reported to contain oleic $(18.6 \%)$, linoleic $(32.8 \%)$, palmitic $(2 \%)$, stearic $(20 \%)$ and linolenic acid $(26.6 \%)$ and the oil has been reported as edible (Rukmini, 1978). Different types of chemical compounds are reported i.e. coumarino-lignan, glucosinolates, cleomeolide, stigmasta-5, kaempeferide-3-glucuronide (Sudhakar et al., 2006). Subsequent to a large number of claims about the wide range of traditional medicinal properties of the plant, considerable efforts have been made to identify its efficacy as a curative agent through pharmacological investigations. The plant reported to possess antipyretic (Devi et al., 2003), antidiarrhoeal (Devi et al., 2002), anti-inflammatory (Parimaladevi et al., 2003), immunomodulatory (Tiwari et al., 2004), local anesthetic activities (Singh \& West, 1991), antimalarial activity (Saxena et al., 2000). Traditional medicines hold a great opportunities as sources of easily available, effective healing agents to the people, particularly in tropical developing countries, including Bangladesh. It is in this context that the people consume several plants or plant-derived preparations to cure different diseases. In the present study we evaluated antinociceptive, cytotoxic and antibacterial potential of methanol extracts of leaves of C. viscosa.

\section{Materials and Methods}

Plant material collection and extraction

The leaves of Cleome viscosa L., Cleomaceae, were collected from the Khulna, Bangladesh in July 2007, and were taxonomically identified by experts at the Bangladesh National Herbarium (accession number: 34556). About $400 \mathrm{~g}$ of powdered leaves were taken in a clean, flat-bottomed glass container and soaked in 1,300 $\mathrm{mL}$ of $80 \%$ methanol. The container with its contents was 
sealed and kept for a period of seven days accompanying occasional shaking and stirring. The whole mixture then underwent a coarse filtration by a piece of cotton followed by a filtration through Whatmann filter paper and the filtrate thus obtained was concentrated using a rotary evaporator (Bibby RE200, Sterilin Ltd., U.K.) to get the crude extract.

\section{Drugs}

Diclofenac sodium(Opsonin Chemical Industries Ltd, Bangladesh), Loperamide (Square Pharmaceuticals Ltd., Bangladesh), Gentamycin (Square Pharmaceuticals Ltd., Bangladesh), DMSO (Sigma Aldrich, Dhaka), Acetic acid (Azad Chemicals Ltd., Dhaka).

\section{Animals}

Young Swiss-albino mice of either sex, weighing 20-25 g, purchased from the Animal Research Branch of the International Centre for Diarrhoeal Disease and Research, Bangladesh (ICDDR, B) were used for the test. The animals were kept at animal house (Pharmacy Discipline, Khulna University) for adaptation after their purchase under standard laboratory conditions (relative humidity $55-65 \%$, room temperature $25 \pm 2{ }^{\circ} \mathrm{C}$ and $12 \mathrm{~h}$ light-dark cycle) and fed with standard diets (ICDDR, B formulated) and had free access to tap water. The experimental met the national guidelines on the proper care and use of animals. The Institutional Animal Ethics Committee (IAEC) approved the experimental protocol.

\section{Phytochemical tests}

Desirable amount of $C$. viscosa extract was solublized in water for phytochemical tests. The extract solution was tested for alkaloids, glycosides, steroids, flavonoids, saponins and tannins according to the protocol described by Evans (1989).

\section{Pharmacological studies}

\section{Antinociceptive activity}

Antinociceptive activity of the crude extract was tested using the model of acetic acid-induced writhing in mice (Ahmed et al., 2007; Roome et al., 2008)The experimental animals were randomly divided into four groups, each consisting of ten animals. Group I was treated as 'control group' which received $1 \%(\mathrm{v} / \mathrm{v})$ Tween- 80 in water at the dose of $10 \mathrm{~mL} / \mathrm{kg}$ of body weight; group II was treated as 'positive control' and was given the standard drug diclofenac sodium at dose of $25 \mathrm{mg} / \mathrm{kg}$ of body weight; group III and group IV were test groups and were treated with the extracts at dose of
250 and $500 \mathrm{mg} / \mathrm{kg}$ of body weight respectively. Control vehicle, standard drug and extracts were administered orally, 30 min prior to acetic acid $(0.7 \%)$ injection in peritoneum. Then after an interval of $10 \mathrm{~min}$, the number of writhes (squirms) was counted for $5 \mathrm{~min}$.

\section{Cytotoxicity test}

The brine shrimps used for cytotoxicity test were obtained by hatching $5 \mathrm{mg}$ of eggs of Artemia salina in natural seawater after incubation at about $29^{\circ} \mathrm{C}$ for $48 \mathrm{~h}$. The larvae (nauplii) were allowed another $48 \mathrm{~h}$ in seawater to ensure survival and maturity before use. Five doses of plant extract $(1,2,4,6,8$ and $10 \mu \mathrm{g} / \mathrm{mL})$ in 5\% DMSO (dimethylsulfoxide) and/or seawater were tested. Each extract preparation was dispensed into clean test tubes in $10 \mathrm{~mL}$ volumes and tested in duplicates. The concentration of DMSO in the vials was kept below 10 $\mu \mathrm{L} / \mathrm{mL}$. For control, same procedure was followed except test samples. After marking the test tubes properly, ten living shrimps were added to each of the 20 vials with the help of a Pasteur pipette (Meyer et al., 1982). The test tube containing the sample and control were then incubated at $29^{\circ} \mathrm{C}$ for $24 \mathrm{~h}$ in a water bath, after which each tube was examined and the surviving nauplii counted. From this, the percentage of mortality was calculated at each concentration.

\section{Antibacterial activity}

The antibacterial activity of $C$. viscosa extract was studied against Staphylococcus saprophyticus, Shigella sonnie, Salmonella typhi, Vibrio cholera, Streptococcus epidermidis, Shigella flexneri and Staphylococcus aureus clinical isolates. All bacterial strains were kindly provided by IMTECH, Chandigarh (India). Cultures of these bacteria were grown in a nutrient broth at $37{ }^{\circ} \mathrm{C}$ and maintained on nutrient agar (Himedia, India) slants at $40{ }^{\circ} \mathrm{C}$. The antibacterial property was studied by the disc diffusion method (Chattopadhyay et al., 2002) using extract $200 \mathrm{mg} /$ disc. Control disks contained solvents only $(50 \%$ aqueous ethanol). Gentamycin was used as positive controls. Minimum inhibitory concentration (MIC) was evaluated by the micro dilution method using $5 \mathrm{~mL}$ of liquid broth with different concentrations of extract (Ahmad \& Beg, 2007; Bayoud et al., 2007).

\section{Statistical analysis}

Student's $t$-test was used to determine a significant difference between the control group and experimental groups. 


\section{Results}

\section{Preliminary phytochemical analysis}

Results of different chemical tests on the methanol crude leaves extract of $C$. viscosa showed the presence of alkaloids, glycosides, steroids, flavonoids, saponins and tannins.

\section{Antinociceptive activity}

Table 1 showed the effect of the methanol extract of $C$. viscosa on acetic acid-induced writhing in mice. At dose of 250 and $500 \mathrm{mg} / \mathrm{kg}$ of body weight, the extract produced about $35.80 \%$ and $47.94 \%$ writhing inhibition in test animals, respectively. The results were statistically significant $(p<0.001)$ and were comparable to the standard drug diclofenac sodium, which showed about $64.17 \%$ writhing inhibition at the dose of $25 \mathrm{mg} / \mathrm{kg}$ $(p<0.001)$.

\section{Cytotoxic activity}

In brine shrimp lethality bioassay (Table 2), the extract showed lethality against the brine shrimp nauplii. It showed different mortality rate at different concentrations. From the plot of percent mortality versus log concentration on the graph paper LC50 and LC90 were deduced (LC50: $28.18 \mu \mathrm{g} / \mathrm{mL}$; LC90: $112.20 \mu \mathrm{g} /$ $\mathrm{mL})$.

In vitro antibacterial activities

The extract of $C$. viscosa exhibited significant in vitro antibacterial activity (Table 3) against Staphylococcus saprophyticus, Shigella sonnie, Salmonella typhi, Vibrio cholera, Streptococcus epidermidis, Shigella flexneri and Staphylococcus aureus with the zones of inhibition ranging from 10.76 to $16.34 \mathrm{~mm}$.

Table 1. Effects of Cleome viscosa L., Cleomaceae, crude leaves extract on writhing effect on acetic acid induced mice.

\begin{tabular}{lccccc}
\hline Treatment & Dose $(\mathrm{mg} / \mathrm{kg})$ & Mean writhing & \% Inhibition & SD & $p$ value (One way Anova) \\
\hline Experimental control (1\% Tween80) & 10 & $33.50 \pm 1.33$ & - & 2.97 & $p<0.001$ \\
Positive control (diclofenac sodium) & 25 & $12.00 \pm 1.24$ & 64.17 & 2.76 & $p<0.001$ \\
Test sample & 250 & $20.50 \pm 2.01$ & 35.80 & 2.87 & $p<0.001$ \\
Test sample & 500 & $17.7 \pm 1.93$ & 47.94 & 3.85 & $p<0.001$ \\
\hline
\end{tabular}

Test sample: C. viscosa crude extract: 30 min after treatment, $0.7 \%$ acetic acid was injected i.p. 10 min after injection writhing responses was recorded for 5 min. $\mathrm{n}=5$.

Table 2. Brine shrimp lethality bioassay of Cleome viscosa L., Cleomaceae, crude leaves extract.

\begin{tabular}{|c|c|c|c|c|c|c|c|}
\hline \multirow{2}{*}{ Test sample } & \multirow{2}{*}{$\begin{array}{c}\text { Conc. } \\
(\mu \mathrm{g} / \mathrm{mL})\end{array}$} & \multicolumn{3}{|c|}{ No. of alive shrimp } & \multirow{2}{*}{$\%$ mortality } & \multirow{2}{*}{$\begin{array}{c}\mathrm{LC} 50 \\
(\mu \mathrm{g} / \mathrm{mL})\end{array}$} & \multirow{2}{*}{$\begin{array}{c}\mathrm{LC} 90 \\
(\mu \mathrm{g} / \mathrm{mL})\end{array}$} \\
\hline & & Test 1 & Test 2 & Average & & & \\
\hline \multirow{6}{*}{$\begin{array}{c}\text { Methanolic } \\
\text { extract }\end{array}$} & 1 & 8 & 7 & 7.5 & 25 & \multirow{6}{*}{28.18} & \multirow{6}{*}{112.20} \\
\hline & 2 & 7 & 7 & 7 & 30 & & \\
\hline & 4 & 5 & 6 & 5.5 & 45 & & \\
\hline & 6 & 4 & 5 & 4.5 & 55 & & \\
\hline & 8 & 2 & 2 & 2 & 80 & & \\
\hline & 10 & 0 & 0 & 0 & 100 & & \\
\hline
\end{tabular}

Table 3. In vitro antibacterial activity of the methanolic crude leaves extract of Cleome viscosa L., Cleomaceae.

\begin{tabular}{lcc}
\hline Bacterial stains & C. viscosa $(\mathrm{mm})$ & Control $(\mathrm{mm})$ \\
\hline Staphylococcus saprophyticus & 12.22 & 30.00 \\
Shigella sonnie & 16.34 & 44.88 \\
Salmonella typhi & 14.65 & 36.88 \\
Vibrio cholera & 14.42 & 32.44 \\
Streptococcus epidermidis & 12.45 & 34.28 \\
Shigella flexneri & 10.76 & 28.90 \\
Staphylococcus aureus & 10.80 & 30.50 \\
\hline
\end{tabular}

Control (50\% aqueous ethanol); Diameter of inhibition zones ( $\mathrm{mm})$. 


\section{Discussion}

Plants are employed as important source of medication in many traditional medications (Grover et al., 2002; Keung \& Vallee, 1998; Neves et al., 2009). C. viscosa commonly found tree plant was taken to explore the phytochemical and pharmacological properties as there was very limited work done on the plant. The leaves, which are mostly used as a source of medication in traditional medicines was considered to examine the properties of the plant.

Antinociceptive activity of the methanol extract of $C$. viscosa was tested by acetic acid-induced writhing model in mice. Acetic acid-induced writhing model represents pain sensation by triggering localized inflammatory response. Acetic acid, which is used to induce writhing, causes algesia by liberation of endogenous substances, which in turn excite the pain nerve endings (Taesotikul et al., 2003). Increased levels of PGE2 and PGF2 $\alpha$ in the peritoneal fluid have been reported to be responsible for pain sensation caused by intraperitoneal administration of acetic acid (Derardt et al., 1980). The extract produced significant writhing inhibition comparable to the standard drug diclofenac sodium (Table 1). The polar compounds present in the plant extract may be responsible for the obtained antinociceptive activity. Based on this result it can be concluded that the methanol extract of $C$. viscosa might possess antinociceptive activity.

The cytotoxic activity of the methanol extract of $C$. viscosa was tested by using brine shrimp lethality bioassay. It is a recent well known developed bioassay for the bioactive compounds (Ara et al., 1999; Hartl \& Humph, 2000). The plant is reported to contain saponins (Ghani 2003). There is growing interest in natural saponins caused as much by the scientific aspects extraction and structural analysis of these compounds, as by the fact of their wide spectrum of pharmacological activities; for instance, bactericidal, antiviral, cytotoxic, analgesic, anti-inflammatory, anticancer and antiallergic (Ahmed et al., 2007; Attele et al., 1999). Brine shrimp lethality bioassay indicates cytotoxicity as well as a wide range of pharmacological activities such as antimicrobial, pesticidal, and antitumor (Anderson et al., 1988). The extract was found to show potent activity against the brine shrimp nauplii. Therefore the positive response obtained in this assay suggests that the extract may contain antitumor, antibacterial or pesticidal compounds.

In this experiment, methanolic extract of $C$. viscosa showed moderate sensitivity to the five of the test organisms both gram positive and gram negative type of bacteria. The highest zone on inhibition (16.34 $\mathrm{mm}$ ) was recorded against Shigella sonnie. Moreover, the experiment was only conducted with five species of bacteria as test samples. Therefore further research is essential to evaluate the sensitivity of the plant extract against other species of bacteria, fungi, virus of other microorganisms.

\section{Conclusion}

Finally, it could be suggested that the methanol extract of $C$. viscosa leaves possesses antinociceptive, cytotoxic and antibacterial activities. These facts indicate the scientific basis of $C$. viscosa being used as a traditional medicine. However, further experiments may help to determine the pharmaceutical potentialities of the plant as a medicine.

\section{Acknowledgements}

The authors are thankful to Prof. Dr. Samir Kumar Sadhu, Head, Pharmacy Discipline, Khulna University; Dr. Asish Kumar Das, Assistant professor, Pharmacy Discipline, Khulna University; Dr. Mahiuddin Alamgir, Research Scientist, National Measurement institute (NMI), Australia for their encouragement during the research time. All the informants of the study area are cordially acknowledged for their valuable cooperation.

\section{References}

Ahmed F, Al Mamun AH, Shahid IZ, Rahman AA, Sadhu SK 2007. Antinociceptive, antidiarrhoeal and cytotoxic activity of Aegiceras corniculatum. Orient Pharm Exp Med 7: 191-196.

Ahmad I, Beg AJ 2007. Antimicrobial and phytochemical studies on 45 Indian medicinal plants against multidrug resistant human pathogens. J Ethnopharmacol 74 : 113-23.

Anderson JE, Chang CJ, McLaughlin JL 1988. Bioactive components of Allamanda schottii. J Nat Prod 51: 307-308.

Ara J, Sultana V, Haque SE, Qasim R, Ahmad VU 1999. Cytotoxic activity of marine macro-algae on Artemia salina (brine shrimp). Phytother Res 13: 304-307.

Attele AS, Wu JA, Yuan C 1999. Analgesic effects of different aucpoint stimulation frequencies in humans. Biochem Pharmacol 58: 1685-1693.

Bayoud B, Djilani SE, Legseir B, Ouahrani MR, Djilani A 2007. Antibacterial activity of ethanol extracts and total alkaloids of Datura stramonium and Ruta graveolens. J Life Sci 1: 78-81.

Chattopadhyay D, Arunachalam G, Mandal AB, Sur TK, Mandal SC, Bhattacharya SK 2002. Antimicrobial and anti-infl ammatory activity of folklore: Mellotus peltatus leaf extract. J Ethnopharmacol 82: 229-237.

Chopra RN, Nayar SI, Chopra IC 1956. Glossary of Indian Medicinal Plants. New Delhi, Council of Scientific 
and Industtrial Research, pp. 70-71

Derardt R, Jougney S, Delevalcee F, Falhout M 1980. Release of prostaglandins $\mathrm{E}$ and $\mathrm{F}$ in an algogenic reaction and its inhibition. Eur J Pharmacol 51: 17-24.

Devi BP, Boominathan R, Mandal SC 2003. Evaluation of antipyretic potential of Cleome viscose Linn. (Capparidaceae) extract in rats. J Ethnoparmacol 87: 11-13.

Devi BP, Boominathan R, Mandal SC 2002. Evaluation of anti-diarrheal activity of Cleome viscosa L. extract in rats. Phytomedicine 9: 739-742.

Evans WC 1989. Trease and Evan's Textbook of Pharmacognosy. $13^{\text {th }}$ ed, Cambridge University Press, London, pp 546

Ghani A 2003. Medicinal Plants of Bangladesh-chemical constituents and uses, $2^{\text {nd }} \mathrm{ed}$, The Asiatic Society of Bangladesh, Dhaka, Bangladesh, pp.362-363, 502505.

Grover JK, Yadav S, Vats V 2002. Medicinal plants of India with anti-diabetic potential. J Ethnopharmacol 81: 81-100.

Hartl M, Humpf HU 2000. Toxicity assessment of fumonisins using the brine shrimp (Artemia salina) bioassay. Food Chem Toxicol 38: 1097-1102.

Keung WM, Vallee BL 1998. Kudzu root: An ancient Chinese source of modern antidipsotropic agents. Phytochemistry 47: 499-506.

Kirtikar KR, Basu BD 1984. Indian Medicinal Plants, Vol. I. Allahabad, Lalit Mohan Basu, pp. 181-185.

Mali RG 2010. Cleome viscose (wild mustard): A review on ethnobotany, phytochemistry, and pharmacology. Pharm Biol 48: 105-112.

Meyer BN, Ferrigni NR, Putnam JB, Jacobsen LB, Nichols DE, McLaughlin JL 1982. Brine shrimp: a convenient general bioassay for active plant constituents. Planta Med 45: 31-34.

Nadkararni KM, Nadkarani AK 1976. Indian materia medica popular, vol 1. Bombay: Prakashan pp:498.

Neves JM, Matos C, Moutinho C, Queiroz G, Gomes LR 2009. Ethnopharmacological notes about ancient uses of medicinal plants in Trás-os-Montes (northern of Portugal). J Ethnopharmacol 124: 270-283.

Parimaladevi B, Boominathan R, Mandal SC 2003. Studies on analgesic activity of Cleome viscosa in mice. Fitoterapia 74: 262-266.

Roome T, Dar A, Naqvi S, Ali S, Choudhary MI 2008. A study on antioxidant, free radical scavenging, anti-inflammatory and hepatoprotective actions of Aegiceras corniculatum (stem) extracts. $J$ Ethnopharmacol 118: 514-521.

Rukmini C 1978. Chemical nutritional and toxicological evaluation of the seed oil of Cleome viscosa. Ind $J$ Med Res 67: 604-607.

Saxena BR, Koli MC, Saxena RC 2000. Preliminary ethnomedical and phytochemical study of Cleome viscosa L. Ethnobotany 12: 47-50.

Singh PD, West ME 1991. Pharmacological investigations of sticky viscome extract (Cleome viscosa Linn) in rats, mice and guinea-pigs. Phytother Res 5: 82-84.

Sudhakar M, Rao ChV, Rao PM, Raju DB 2006. Evaluation of antimicrobial activity of Cleome viscose and Gmelina asiatica. Fitoterapia 77: 47-49.

Taesotikul T, Panthong A, Kanjanapothi D, Verpoorte R, Scheffer JJC 2003. Anti-inflammatory, antipyretic and antinociceptive activities of Tabernaemontana pandacaqui Poir. J Ethnopharmacol 84: 31-33.

Tandon S, Chatterjee A, Chattopadhyay SK, Kaur R, Gupta AK 2010. Pilot scale processing technology for extraction of Cliv-92: A combination of three coumarinolignoids cleomiscosins A,B and $\mathrm{C}$ from Cleome viscosa. Industrial Crops Prod 31: 335-343.

Tiwari U, Rastogi B, Thakur S, Jain S, Jain NK 2004. Studies on the immunomodulatory effects of Cleome viscosa. Indian J Pharm Sci 66: 171-176.

\section{*Correspondence}

Utpal Bose

s107, School of Biotechnology and Biomolecular Sciences, University of New South Wales, NSW- 2052, Australia utpal.bose@unsw.edu.au Tel. +61431398923 